•综述・

\title{
黄河流域湿地水鸟多样性保护对策
}

\author{
孙工棋 ${ }^{1,2}$ 张明祥 ${ }^{1,2}$ 雷光春 ${ }^{1,2 *}$ \\ 1 (北京林业大学生态与自然保护学院, 北京 100083) \\ 2 (黄河流域生态保护国家林草局重点实验室, 北京 100083)
}

\begin{abstract}
摘要: 黄河是中华文明的发源地, 被誉为母亲河, 是两岸社会经济发展的保障, 切实保护好黄河流域湿地生态系 统，事关中华民族伟大复兴的千秋大计。黄河流域湿地总面积为 391 万ha，其中 $80.4 \%$ 分布在上游，中游和下游分别 仅 $12.5 \%$ 和 $7.1 \%$ 。黄河流域是东亚-澳大利西亚候鸟迁徙路线和中亚候鸟迁徙路线上水鸟的关键栖息地，一些迁徙 水鸟最关键的栖息地均分布在黄河流域，如黑颈鹤(Grus nigricollis)、白鹤(G. leucogeranus)、丹顶鹤(G. japonensis)、 斑头雁(Anser indicus)、大铇 (Otis tarda)、东方白鹳(Ciconia boyciana)、大天鹅(Cygnus cygnus)、病鼻天鹅(C. olor)、 青头潜鸭(Aythya baeri)等。尽管黄河流域湿地提供的水资源仅占全国的 $2 \%$, 但维持着全国 $12 \%$ 的人口饮水安全和 15\%的耕地用水, 湿地生态系统的脆弱性较高。截至2017年底, 黄河流域已建立各类湿地自然保护地230处, 其中 国家公园2处、国家级自然保护区9处、地方级自然保护区68处、国家湿地公园145处、省级湿地公园6处, 湿地保 护率达到 $65 \%$, 高于我国湿地保护 $53 \%$ 的平均水平。然而, 流域尺度现有水鸟生物多样性保护仍然面临不少挑战, 包括全球气候变化、水资源过度利用、水环境污染、栖息地丧失等。为此, 我们提出了建立以国家公园为主体的 湿地保护地体系、开展濒危候鸟栖息地修复和强化黄河流域综合管理的体制机制建设等建议。
\end{abstract}

关键词: 黄河流域; 湿地; 水鸟; 生物多样性; 保护对策; 水资源管理

\section{Wetland water bird biodiversity conservation strategies in the Yellow River basin}

\author{
Gongqi Sun ${ }^{1,2}$, Mingxiang Zhang ${ }^{1,2}$, Guangchun Lei ${ }^{1,2 *}$ \\ 1 School of Ecology and Nature Conservation, Beijing Forestry University, Beijing 100083 \\ 2 Key Laboratory of Ecological Protection in the Yellow River Basin of National Forestry and Grassland Adiministration, \\ Beiijing 100083
}

\begin{abstract}
The Yellow River plays an important Part Chinese History, and is considered the mother river for China. The river basin is rich in wetland resources, which helps social and economic development. Therefore, effective conservation of this wetland ecosystem is important for China's future prosperity. According to the 2nd National Wetland Inventory, there are 3.91 million hectares (ha) of wetlands in the river basin. Most wetlands are distributed in the upstream part of the river (80.4\%). Whereas, the middle reaches and lower reaches of the river account for $12.5 \%$ and $7.1 \%$ of wetlands, respectively. Wetlands are key habitats for migratory water birds in the East Asia-Australasia flyway, and the Central Asia Flyway. Some species are critically endangered depending on the Yellow River wetlands, such as Grus nigricollis, G. leucogeranus, G. japonensis, Anser indicus, Otis tarda, Ciconia boyciana, Cygnus cygnus, C. olor, Aythya baeri. Although the river basin retains only $2 \%$ of the country's water resources, it provides drinking water for $12 \%$ of the country's population and irrigation for $15 \%$ of the country's arable land. Unfortunately, the wetland ecosystem is relatively fragile and in need of conservation. To protect the Yellow River wetland ecosystem, 230 wetland protected areas have been established. These protected areas include 2 national parks, 9 national nature reserves, 68 local nature reserves, 145 national wetland parks, and 6 provincial wetland parks. The rate of wetlands being protected exceeds $65 \%$, which is above than national average $53 \%$. However, current conservation efforts are still unable to mitigate key challenges such as climate change, over exploitation of
\end{abstract}

收稿日期: 2020-06-04; 接受日期: 2020-11-03

基金项目: 第二次青藏高原科学考察研究(2019QZKK0304)

* 通讯作者 Author for correspondence. E-mail: guangchun.lei@foxmail.com 
water resources, pollution, and the degradation of habitats for water birds. A list of comprehensive wetland biodiversity conservation strategies has been proposed which include: establishing a river basin protected area system, conserving and restorating key habitats for endangered water birds, and strengthening an integrating the river basin management with effective mechanisms.

Key words: Yellow River; wetlands; water bids; biodiversity; conservation strategies; water management

全球20\%的鸟类以湿地为主要栖息地(Cristina et al, 2010)。然而, 因湿地普遍遭受破坏, 湿地水鸟 是全球受威胁比例最高的类群之一。第四次全球水 鸟种群评估(WPE4)结果显示, 近6\%的水鸟种群已 灭绝，40\%处于下降趋势，34\%保持稳定，仅有 $17 \%$ 处于增长趋势(Almond et al, 2020)。其中, 亚洲湿地 水鸟种群下降趋势最为明显, $62 \%$ 的已知种群呈现 下降和灭绝趋势。湿地水鸟是湿地生态系统的重要 指示物种, 其多样性及变化反映了湿地水质水量、 生态服务功能及植被组成等生态特征(Grabas et al, 2008)。气候变化、围垦、工农业污染、城市化进程、 土地利用变化等导致湿地减少和退化, 对全球水鸟 的分布格局及种群变化产生了重要影响(Ramsar Convention Secretariat, 2018)。全球共有9大候鸟迁 徙路线, 其中中亚、东亚-澳大利西亚和西太平洋3 条迁徙路线经过中国, 因此, 中国湿地在全球水鸟 保护中具有重要意义。

黄河是我国重要的生态屏障, 横跨青藏高原、 黄土高原、华北平原, 拥有三江源、祁连山等多个 国家公园和国家重点生态功能区，以仅占全国2\% 的水资源量支撑着 $12 \%$ 的人口饮水安全和 $15 \%$ 的耕 地用水(曹静宇等, 2018; 陈耀, 2019; 牀杰等, 2020)。黄河流域湿地类型多样, 包括近海与海岸、 河流、湖泊、沼泽和人工湿地 5 类, 总面积 390 万ha (表1), 约占全国湿地面积的6\%。黄河流域的湿地以 沼泽和河流为主, 其中沼泽湿地 233.79 万h, 占全 流域湿地总面积的 $59.9 \%$, 河流湿地 102.94 万h, 占 $26.4 \%$ 。上游源头、中游河套地区以及河口三角洲 地区等湿地水鸟资源丰富, 在全球水鸟保护中发挥 着重要作用, 为中亚和东亚-澳大利西亚两大迁徙 路线上的水鸟提供了重要的繁殖地、停歇地和越冬 地。然而, 黄河流域湿地生态系统的脆弱性较高, 气候变化、过牧、采沙、排污、围垦等均影响着黄 河流域的湿地生态健康(张金良等, 2018; 樊杰等, 2020)。本研究回顾了黄河流域湿地的空间分布格局 及水鸟多样性分布的关键区域和保护现状, 剖析了
该区域湿地资源面临的主要问题, 提出了水鸟多样 性保护与管理的建议, 旨在为黄河流域生态保护和 高质量发展国家战略的实施提供科学依据。

\section{表1 黄河流域各类型湿地面积 $\left(\times 10^{4} \mathrm{ha}\right)$}

Table 1 Areas of different types of wetland the Yellow River basin ( $\times 10^{4}$ ha)

\begin{tabular}{|c|c|c|}
\hline \multicolumn{2}{|c|}{ 湿地类 Wetland 湿地型 Wetland type } & 面积 Areas \\
\hline \multicolumn{2}{|c|}{ 近海与海岸湿地河口水域 Estuary } & 0.38 \\
\hline \multirow[t]{5}{*}{ Coastal } & 淤泥质海滩 Mudflats & 3.76 \\
\hline & 潮间盐水沼泽 Tidal & 0.60 \\
\hline & 三角洲/沙洲/沙岛 Delta & 0.28 \\
\hline & 浅海水域 Sublittoral & 1.50 \\
\hline & 小计 Sub-total & 6.52 \\
\hline \multirow[t]{4}{*}{ 河流湿地 River } & 永久性河流 Permanent river & 59.78 \\
\hline & 季节性或间歇性河流 Seasonal river & 15.22 \\
\hline & 洪泛平原 Floodplain & 27.95 \\
\hline & 小计 Sub-total & 102.94 \\
\hline \multirow[t]{5}{*}{ 湖泊湿地 Lake } & $\begin{array}{l}\text { 永久性淡水湖 Permanent freshwater } \\
\text { lake }\end{array}$ & 20.60 \\
\hline & 永久性咸水湖 Permanent saline lake & 1.93 \\
\hline & $\begin{array}{l}\text { 季节性淡水湖 Seasonal freshwater } \\
\text { lake }\end{array}$ & 0.17 \\
\hline & 季节性咸水湖 Seasonal saline lake & 3.79 \\
\hline & 小计 Sub-total & 26.49 \\
\hline \multirow{9}{*}{$\begin{array}{l}\text { 沼泽湿地 } \\
\text { Marshes }\end{array}$} & 沼泽化草甸 Fen & 203.94 \\
\hline & $\begin{array}{l}\text { 季节性咸水沼泽 Seasonal saline } \\
\text { marshes }\end{array}$ & 6.99 \\
\hline & 内陆盐沼 Intermittent saline swamp & 5.99 \\
\hline & 森林沼泽 Swamp forest & 0.04 \\
\hline & 灌丛沼泽 Swamp shrub & 4.40 \\
\hline & 草本沼泽 Swamp grass & 12.43 \\
\hline & 地热湿地 Geothermy wetland & 0.0008 \\
\hline & 淡水泉/绿轴 Freshwater spring & 0.0025 \\
\hline & 小计 Sub-total & 233.79 \\
\hline \multirow{6}{*}{$\begin{array}{l}\text { 人工湿地 } \\
\text { Artificial }\end{array}$} & 库塘 Reservior & 14.59 \\
\hline & 运河、输水河 Canal & 3.40 \\
\hline & 稻田/冬水田 Paddy & 0.77 \\
\hline & 水产养殖场 Aquafarm & 1.70 \\
\hline & 盐田 Saltern & 1.41 \\
\hline & 小计 Sub-total & 20.46 \\
\hline \multicolumn{2}{|l|}{ 总计 Total } & 390.20 \\
\hline
\end{tabular}




\section{黄河流域湿地候鸟栖息地及水鸟多样性}

\section{1 黄河上游栖息地及多样性}

黄河上游包括龙羊峡以上的黄河源区及龙羊 峡-河口镇的上游区域, 湿地总面积为313.66万ha (表2)。其中, 河源区湿地面积219.08万ha, 占黄河上 游湿地总面积的 $69.9 \%$; 龙羊峡-河口镇湿地总面积 94.58万ha (国家林业局调查规划设计院, 2016)。

黄河源头以沼泽化草甸湿地和泥炭地为主, 包 括面积达 185.80 万ha的若尔盖湿地(占黄河源区湿 地总面积的84.8\%) (马骅等, 2019), 是黑颈鹤(Grus nigricollis)、斑头雁(Anser indicus)的主要繁殖地(李 扎西姐等, 2017)。其次是湖泊湿地, 面积15.8万ha (占河源区湿地总面积的7.8\%) (国家林业局调查规 划设计院, 2016)。鄂陵湖、扎陵湖、星星海等湖泊 湿地是全球水鸟保护的关键区域，为黑颈鹤、灰鹤 (Grus grus)、斑头雁、赤麻鸭(Tadorna ferruginea)、 玉带海雕 (Haliaeetus leucoryphus)、大鵟 (Buteo hemilasius)、红隼 (Falco tinnunculus)、猎隼 (F. cherrug)等提供了重要栖息地, 是中亚迁徙路线上 的主要候鸟繁殖地和停歇地(窦亮等, 2013)。本课题 组自2016年起对河源区进行水鸟生物多样性监测, 每年记录到的水鸟数量为 26,000 余只, 其中记录到 的斑头雁最大种群数量约 7,000只, 占全球种群的 $12.5 \%$; 赤麻鸭数量为 6,030 只, 占全球种群的 $8.5 \%$; 棕头鸥(Larus brunnicephalus)约4,000只, 占全球种 群的 $2.9 \%$; 普通鸬鹚 (Phalacrocorax carbo) 数量为 2,755 只, 占全球种群数量的 $2.76 \%$; 针尾鸭(Anas acuta)数量为 4,844 只, 占全球种群数量的 $2 \%$ (表3)。

源头的河流湿地总面积为 14.35 万ha, 占河源 区湿地总面积的7.1\%，400余条大小河流纵横交错， 与源头沼泽湿地和湖泊湿地交织(国家林业局调查 规划设计院, 2016)。河流水域、浅滩为鹳类(主要为
黑鹳(Ciconia nigra))、行璚类、雁鸭类等提供了停 歇地(张国钢等, 2013)。

源头之下的龙羊峡-河口镇以河流湿地和河套 地区的湖泊一沼泽湿地为主体，其中，河套地区的 关键栖息地，如宁夏沙湖、内蒙古乌海和乌梁素海 是国内外著名候鸟栖息地，位于东亚-澳大利西亚 及中亚-印度两条迁徙路线上，是重要的水鸟繁殖 地和停歇地(李长看等, 2010; Zhang et al, 2017), 为 超过全球16\%的疮鼻天鹅(Cygnus olor)、11\%的大天 鹅(Cygnus cygnus)、16\%的大鸨(Otis tarda)、28.6\% 的青头潜鸭(Aythya baeri)、35.6\%的白骨顶(Fulica atra)、 $4 \%$ 的棕头鸥、 $7.8 \%$ 的红嘴鸥 (Larus ridibundus)、6\%的凤头辟鸟曆 (Podiceps cristatus)和 6.35\%的黑翅长脚鹬(Himantopus himantopus)提供 了栖息地(李长看等, 2019)。

\section{2 黄河中游栖息地及多样性}

黄河中游包括第二阶梯的内蒙古高原和黄土 高原，从甘肃河口镇到河南花园口，河段及流域湿 地总面积约48.79万ha (表2), 占黄河流域湿地总面 积的12.5\% (国家林业局, 2015)。优质的湿地资源为 众多水鸟提供了栖息地, 有 22 种水鸟的种群数量超 过迁徙路线上该物种种群数量的 $1 \%$, 主要以三门 峡和黄河故道为栖息地, 是中游湿地水鸟多样性保 护的关键地区(表4)（李淑红等, 2017; 何冰和王保 星, 2018)

黄河中游以河流湿地为主，面积为 38.26 万ha, 占中游湿地总面积的 $78.4 \%$ 。黄河故道是全球水鸟 迁徙的重要通道, 是大铇在东亚的重要越冬栖息地 (赵文珍等，2018)。2007-2017年间针对河南黄河湿 地水鸟多样性的调查结果显示, 大铇最大观测种群 数量为352只, 占东亚种群总数的 $20 \%$ (Alonso \& Palacin, 2010; 李长看等, 2013; 朱龙飞等, 2018)。

表2 黄河流域各类湿地面积(分布比例 \%)

Table 2 Area (proportion) of all kinds of wetlands in the Yellow River basin

\begin{tabular}{lllll} 
湿地类 Wetland & 全流域 Basin $\left(\times 10^{4}\right.$ ha) & 上游 Upper reach $\left(\times 10^{4}\right.$ ha) & 中游 Middle reach $\left(\times 10^{4}\right.$ ha $)$ & 下游 Lower reach $\left(\times 10^{4}\right.$ ha $)$ \\
\hline 近海与海岸湿地 Coastal & $655.16(1.7 \%)$ & $0(0.0 \%)$ & $0(0.0 \%)$ & $6.52(23.5 \%)$ \\
河流湿地 River & $102.94(26.4 \%)$ & $48.80(15.6 \%)$ & $38.26(78.4 \%)$ & $15.88(57.2 \%)$ \\
湖泊湿地 Lake & $26.49(6.8 \%)$ & $26.10(8.3 \%)$ & $0.36(0.7 \%)$ & $0.02(0.1 \%)$ \\
沼泽湿地 Marshes & $233.79(59.9 \%)$ & $229.29(73.1 \%)$ & $1.66(3.4 \%)$ & $2.85(10.2 \%)$ \\
人工湿地 Artificial & $20.46(5.2 \%)$ & $9.46(3.0 \%)$ & $8.51(17.5 \%)$ & $2.49(9.0 \%)$ \\
合计 Total & $390.20(100.0 \%)$ & $313.66(100 \%)$ & $48.79(100 \%)$ & $27.76(100 \%)$ \\
\hline
\end{tabular}


表3 黄河源区生物多样性关键区域(扎陵湖和鄂陵湖)水鸟 物种及数量

Table 3 Water bird species and quantity in the biodiversity key areas of the source area in the Yellow River (Zhaling Lake and Eling Lake)

\begin{tabular}{|c|c|c|}
\hline $\begin{array}{l}\text { 鸟种 } \\
\text { Species }\end{array}$ & $\begin{array}{l}\text { 最大观测数 } \\
\text { Max. count }\end{array}$ & $\begin{array}{l}1 \% \text { 标准 } \\
1 \% \text { criterion }\end{array}$ \\
\hline 斑头雁 Anser indicus & 7,000 & 560 \\
\hline 赤麻鸭 Tadorna ferruginea & 6,030 & 710 \\
\hline 针尾鸭 Anas acuta & 4,844 & 2,400 \\
\hline 凤头潜鸭 Aythya fuligula & 34 & 2,400 \\
\hline 普通秋沙鸭 Mergus merganser & 46 & 710 \\
\hline 凤头辟鳥鹤 Podiceps cristatus & 214 & 350 \\
\hline 黑颈辟鹤 Podiceps nigricollis & 19 & 1,000 \\
\hline 黑鹳 Ciconia nigra & 2 & 1 \\
\hline 普通玷鸟鹚 Phalacrocorax carbo & 2,755 & 1,000 \\
\hline 骨顶鸡 Fulica atra & 143 & 20,000 \\
\hline 灰鹤 Grus grus & 16 & 10 \\
\hline 黑颈鹤 Grus nigricollis & 8 & 100 \\
\hline 蒙古沙衍 Charadrius mongolus & 72 & 790 \\
\hline 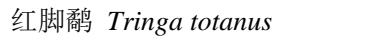 & 28 & 1,000 \\
\hline 青脚滨捅 Calidris temminckii & 1 & 1,000 \\
\hline 普通燕鴻 Glareola maldivarum & 318 & 28,800 \\
\hline 棕头鸥 Larus brunnicephalus & 4,000 & 1,400 \\
\hline 渔鸥 Ichthyaetus ichthyaetus & 500 & 1,000 \\
\hline 普通燕鸥 Sterna hirundo & 318 & 1,000 \\
\hline
\end{tabular}

$1 \%$ 标准即占全球迁徙路线上鸟类种群数量的 $1 \%$, 为衡量全球重要 鸟区(IBA)的关键标准。

$1 \%$ criterias is $1 \%$ of the bird population on the global migration routes, which is the key criterias to measure the global important bird areas (IBA).

2018年河南民权黄河故道的水鸟调查发现，该区为 青头潜鸭的重要栖息地, 其最大观测种群数量 143 只(李长看等, 2019) (表4)。

其次为人工湿地, 面积为 8.51 万ha, 占中游湿 地总面积的 $17.4 \%$ 。三门峡是大天鹅的关键越冬地, 每年有超过全球 $11 \%$ 的大天鹅种群来此越冬 ${ }^{(1)}$ 。这里 水鸟资源丰富，调查记录有国家I级保护水鸟东方 白鹳(Ciconia boyciana)、黑鹳、大鸨、白尾海雕 (Haliaeetus albicilla)、白肩雕(Aquila heliaca)、金雕 (A. chrysaetos)、玉带海雕、白头鹤(Grus monacha)、 丹顶鹤(Grus japonensis)和白鹤(G. leucogeranus), 国家 II 级保护水鸟白鹈脶(Pelecanus onocrotalus)、 小天鹅(Cygnus columbianus)、驾春(Aix galericulata)、

(1) 李刚 (2007) 内蒙古河套灌区节水对乌梁素海的影响研究. 硕士学 位论文, 中国农业科学院研究生院, 北京.
表4 黄河中游 22 种超过迁徙路线上种群数量 $1 \%$ 的迁徙水 鸟详细信息

Table 4 Twenty-two migratory water birds over 1\% of the population in the middle reach of the Yellow River

\begin{tabular}{|c|c|c|}
\hline $\begin{array}{l}\text { 鸟种 } \\
\text { Species }\end{array}$ & $\begin{array}{l}\text { 最大观测数量 } \\
\text { Max. count }\end{array}$ & $\begin{array}{l}1 \% \text { 标准 } \\
1 \% \text { criterion }\end{array}$ \\
\hline 凤头䴙鹰 Podiceps cristatus & 1,500 & 250 \\
\hline 黑颈鶋鷹 Podiceps nigricollis & 130 & 100 \\
\hline 大天鹅 Cygnus cygnus & 6,600 & 600 \\
\hline 疮鼻天鹅 Cygnus olor & 332 & 20 \\
\hline 赤颈鸭 Anas penelope & 5,500 & 5,000 \\
\hline 赤膀鸭 Anas strepera & 6,300 & 5,000 \\
\hline 赤嘴潜鸭 Netta rufina & 1,855 & 1,000 \\
\hline 骨顶鸡 Fulica atra & 35,630 & 1,000 \\
\hline 黑翅长脚敄 Himantopus himantopus & 1,587 & 250 \\
\hline 金眶行 Charadrius dubius & 260 & 250 \\
\hline 棕头鸥 Larus brunnicephalus & 4,000 & 1,000 \\
\hline 红嘴鸥 Larus ridibundus & 7,781 & 1,000 \\
\hline 遗鸥 Larus relictus & 143 & 120 \\
\hline 普通燕鸥 Sterna hirundo & 700 & 250 \\
\hline 大铇 Otis tarda & 352 & 22 \\
\hline 青头潜鸭 Aythya baeri & 143 & 5 \\
\hline 普通扸鹚 Phalacrocorax carbo & 2,800 & 1,000 \\
\hline 白琵鹭 Platalea leucorodia & 1,860 & 100 \\
\hline 苍鹭 Ardea cinerea & 10,000 & 10,000 \\
\hline 夜鹭 Nycticorax nycticorax & 15,000 & 10,000 \\
\hline 黑尾塍鹬 Limosa limosa & 2,600 & 1,600 \\
\hline 扸鹚 Phalacrocorax carbo. & 3,000 & 1000 \\
\hline
\end{tabular}

㝨羽鹤(Anthropoides virgo)、白额雁(Anser albifrons) 等(时良等, 2009)。

\section{3 黄河下游栖息地及多样性}

黄河下游从河南花园口到河口, 湿地总面积 27.76万ha (表2), 占黄河湿地总面积的 $7.1 \%$ 。下游 湿地主要以河流、滨海和沼泽湿地为主。

黄河下游的河流湿地主要为雁鸭类和鹗类提 供栖息地, 是全球鸟类迁徙的重要通道。河流湿地 面积为 15.88 万h, 占下游湿地总面积的 $57.2 \%$, 为 黑鹳、白额雁、大天鹅、小天鹅、鹗春、灰鹤、苍 鹭(Ardea cinerea)等提供了繁殖地和越冬地。沼泽湿 地面积为 2.85 万ha, 占下游湿地总面积的 $10.2 \%$, 主 要为依河流湿地分布的河漫滩和草甸沼泽湿地, 为 苍鹭、大白鹭、灰鹤、大铇等提供了繁殖地和迁徙 停歇地。

滨海湿地面积为 6.52 万ha, 占黄河下游湿地总 面积的 $23.5 \%$, 这里有全世界暖温带最年轻、保存最 
完整、总面积最大的滨海湿地——黄河三角洲湿地 (国家林业局, 2015; 刘佳琦等, 2017; 卢英俊等, 2018)。这里为东北亚内陆-环西太平洋和东亚-澳大 利西亚两大鸟类迁徙路线上的重要停歇地、越冬地 和繁殖地, 在此栖息的鸟类中有24种超过全球种群 数量的 $1 \%$, 被誉为鸟类重要的“国际机场” (张晓龙 等, 2009; 黄子强等, 2018a; 吕丽, 2019 ${ }^{1}$ )。黄河三角 洲自然保护区内有7种鹤类栖息, 为全球种群 $54.5 \%$ 的丹顶鹤、12.93\%的病鼻天鹅、13.13\%的豆雁(Anser fabalis)、39.6\%的青头潜鸭提供了越冬栖息地(王刚, $2010^{2}$; 董林水等, 2018; 黄子强等, 2018a), 为占全 球种群 $5.17 \%$ 的斑尾滕鵤(Limosa lapponica)、 $5.4 \%$ 的黑尾滕㛚 (L. limosa)、14\%的东方白鹳、14.12\%的 黑嘴鸥(Larus saundersi)、18.6\%的黑腹滨璚(Calidris alpina)、63.68\%的灰斑行鸟(Pluvialis squatarola)、 97.3\%的环颈彻(Charadrius alexandrinus)、97.7\%的 白腰杓敄(Numenius arquata)等提供了重要的繁殖 栖息地(张晓龙等, 2009; 王刚, 2010²; 吕丽, 2019 ${ }^{\circledR}$ ) (表5)。

\section{2 黄河流域湿地水鸟面临的主要威胁}

黄河流域湿地候鸟保护面临的主要问题是水 鸟适宜栖息地面积锐减，栖息地质量下降。与1980 年相比, 2016年黄河流域湿地面积减少了 $13 \%$, 流 域湿地面积总体上呈下降趋势(国家林业局，2015; 赵勇等, 2020)。其中湖泊湿地减少 $24.9 \%$, 沼泽湿地 减少 $20.9 \%$ ，部分天然湿地改造成为人工湿地，导 致人工湿地增加了 $60.0 \%$ (王根绪等, 2004; 王瑞玲 等, 2013)。水资源量短缺已成为黄河流域湿地保护 与管理面临的主要问题, 自1972年起黄河流域开始 出现断流，20世纪90年代其年均耗水量近 300 亿 $\mathrm{Zm}^{3}$ (李建华等, 2004; 李政海等, 2007)。赵勇等(2020) 对黄河流域2016年的缺水状态进行了识别, 发现全 流域年缺水量为 114.1 亿帛, 主要体现在农业生产、 地下水超采及河流生态需水短缺。据黄河流域水资 源保护局公布的数据, 2018年黄河干流及支流共 145 个断面中IV类以下水质断面17个，共占全流域 水质断面总数的 $22.7 \%$ (http://www.yrcc.gov.cn/

(1) 吕丽 (2019) 黄河三角洲湿地鸟类多样性及其生境选择. 硕士学位 论文, 山东农业大学, 泰安.

(2) 王刚 (2010) 黄河三角洲湿地鸟类群落研究. 硕士学位论文, 曲阜师 范大学, 曲阜.
表5 黄河三角洲 25 种超过迁徙路线上种群数量 $1 \%$ 的迁徙 水鸟

Table 5 Twenty-five migratory water birds over $1 \%$ of the population in the Yellow River Delta

\begin{tabular}{|c|c|c|}
\hline $\begin{array}{l}\text { 鸟种 } \\
\text { Species }\end{array}$ & $\begin{array}{l}\text { 最大观测数量 } \\
\text { Max. count }\end{array}$ & $\begin{array}{l}1 \% \text { 标准 } \\
1 \% \text { criterion }\end{array}$ \\
\hline 大天鹅 Cygnus cygnus & 2,000 & 600 \\
\hline 丹顶鹤 Grus japonensis & 218 & 4 \\
\hline 灰鹤 Grus grus & 102 & 10 \\
\hline 白鹤 Grus leucogeranus & 1,500 & 35 \\
\hline 东方白鹳 Ciconia boyciana & 350 & 25 \\
\hline 豆雁 Anser fabalis & 72,200 & 5,500 \\
\hline 疮鼻天鹅 Cygnus olor & 194 & 15 \\
\hline 青头潜鸭 Aythya baeri & 198 & 5 \\
\hline 黑嘴鸥 Larus saundersi & 1,200 & 85 \\
\hline 黑尾塍鹬 Limosa limosa & 8,564 & 1,600 \\
\hline 白腰杓鹬 Numenius arquata & 9,766 & 100 \\
\hline 斑尾塍鹬 Limosa lapponica & 13,976 & 2,700 \\
\hline 中杓㛚 Numenius phaeopus & 2,626 & 400 \\
\hline 红腰杓憰 Numenius madagascariensis & 1,125 & 210 \\
\hline 鹤俑 Tringa erythropus & 594 & 100 \\
\hline 泽鹬 Tringa stagnatilis & 3,803 & 900 \\
\hline 青脚鹬 Tringa nebularia & 701 & 400 \\
\hline 翘嘴璚 Xenus cinereus & 1,022 & 360 \\
\hline 黑腹滨鵤 Calidris alpina & 24,236 & 1,300 \\
\hline 红颈滨鹬 Calidris ruficollis & 3,282 & 3,200 \\
\hline 红腹滨㛚 Calidris canutus & 638 & 560 \\
\hline 尖尾滨鹬 Calidris acuminata & 2,920 & 1,600 \\
\hline 灰斑鸭 Pluvialis squatarola & 15,921 & 2,500 \\
\hline 环颈行 Charadrius alexandrinus & 24,313 & 250 \\
\hline 蒙古沙行 Charadrius mongolus & 371 & 350 \\
\hline
\end{tabular}

other/hhgb/)。黄河流域湿地面临的威胁存在空间异 质性特征，这从不同角度影响了其水鸟多样性。上 游湿地主要是全球气候变化、过牧和农业灌溉退水 污染导致湿地退化, 中游主要是围剭和农业面源污 染，下游受水资源短缺、围艮和外来物种入侵影响 较大。

\section{1 黄河上游水鸟面临主要威胁}

全球气候变化导致鸟类栖息地面积减少, 1975-2000年湿地面积平均每年减少0.54\% (Ramsar Convention Secretariat, 2018)。2000年后由于温度明 显上升，河源区呈现出明显的暖湿化趋势, 2000-2007年湿地面积增加了 29.63\% (燕云鹏等, 2015)。其中，湖泊湿地受全球气候变化影响显著, 数量呈现出先减后增的趋势 (Ramsar Convention 
Secretariat, 2018; 李凤霞等, 2009)。像 盖湖泊数量 由 20 世纪 80 年代末期的 4,000 多个锐减至 2002 年的 不足 2,000 个, 其数量减少了 $50 \%$ 以上, 面积减少了 近3,000 km² (游宇驰等, 2018; 马骅等, 2019)。 1987-2002年间，鄂陵湖和扎陵湖的水位下降了 $1 \mathrm{~m}$ 以上(赵阳等, 2018; 张克新等, 2020)。2007年后全 球气候变暖导致冰川融化, 湖泊水位上升, 湿地面 积呈现大幅增长(杜际增等, 2015)。湖泊湿地水文节 律变化对水鸟栖息地质量影响较大, 水鸟的多样性 和种群数量呈现下降趋势, 尤其是鄂陵湖-扎陵湖 的水鸟种群锐减，黑颈鹤、灰鹤、斑头雁等的繁殖 地和停歇地受到严重威胁(高红梅等, 2019)。

人类活动干扰导致适宜栖息地面积减少，栖息 地质量下降, 主要是过牧对沼泽草甸和高寒泥潭沼 泽湿地的影响。20世纪80年代后期, 黄河上游湿地 出现了沼泽-沼泽化草甸-草甸-沙漠化-荒漠化逆 向演替趋势，湿地面积锐减(王根绪等，2004; 温小 洁和姚顺波, 2018; 杨瑞瑞等, 2018)。近10年来, 仅 乌梁素海的水鸟就减少近百种(灵燕, $2018^{\circledR}$; 赵格 日乐图等, 2018), 疮鼻天鹅、棕头鸥和红嘴鸥等重 要水鸟的繁殖栖息地受到威胁(李长看等, 2019)

点面源污染导致水鸟栖息地质量下降。地表水 和地下水污染对黄河上游湿地生态产生重要影响 (张少文, 2005)。黄河上游水质较好, 但点源污染在 城市河段的干支流较为严重, 并存在空间异质性特 点, 即支流污染程度明显高于干流(张威和付新峰, 2011)。20世纪80年代前污染主要来源于大中城市和 工业区发展; 80年代后, 在原有污染河段未能得到 有效控制的情况下，水污染范围不断扩大(齐贺停 和汪雁, 2004)。地下水在重大污染源附近和地表水 受污染严重的区域也受到污染(高宗军和冯国平, 2020), 仅包头市区每年的 1.29 亿 $\mathrm{m}^{3}$ 废污水在通过 沟渠进入黄河前, 就有 320 万 $\mathrm{m}^{3}$ 渗入地下, 导致区 域的潜水优良率仅为潜水总面积的 $37.3 \%$ 。上游地 区的面源污染主要集中在兰州以下的灌溉农业发 达地区。灌溉等对黄河流域水资源的影响增大, 河 流水文受闸坝调节和农业灌溉的影响较大, 灌区节 水与水淹平衡的矛盾突出(沈彦俊等, 2018), 水文节 律受闸坝影响较大, 影响上游湿地生态特征, 从而 对水鸟栖息地质量产生较大影响并影响了上游湿

(1) 灵燕 (2018) 内蒙古乌梁素海非雀形目鸟类时空分布特征及保护管 理研究. 硕士学位论文, 内蒙古师范大学, 呼和浩特.
地的水鸟多样性。2001-2019年调查结果显示, 水鸟 种数呈现出减少趋势, 由2001年的95种(马强等, 2003)减少到2019年的87种(高红梅等, 2019)。

\section{2 黄河中游水鸟面临主要威胁}

黄河中游，围垦导致水鸟栖息地面积减少，农 业面源污染使得水鸟栖息地质量下降。黄河流域为 农业文明的发祥地，农业经济发达，湿地围垦问题 突出, 影响了黄河中游水沙平衡, 导致水资源过度 消耗、水质水量下降。湿地退化，水鸟栖息地面积 减少、质量下降(高鹏, 2010)。而且黄河中游的农田 灌溉回水导致的土壤盐渍化问题突出(李冬雪等, 2020)。中游水系的污染主要来自上游重工业区污染 物排放和农业面源污染(张和军和孟庆伟, 2006)。黄 河中游农业面源污染严重, 影响了湿地生态系统特 征，水鸟栖息地质量受影响较大，水鸟生物多样性 和种群数量都受到影响。据不完全统计, 1987-2002 年，黄河中游湿地面积减少 20\%（王根绪等，2004; 王瑞玲等，2013)。同时，水沙双减对黄河下游及河 口地区也会产生综合影响，中游的黄土沟壑区淤地 坝疏于管理，存在极端降雨引发垮塌和大面积土沙 流出的风险(沈彦俊等, 2018)。湿地面积减少导致水 鸟栖息地也不同程度地减少，水鸟多样性呈现下降 趋势。

\section{3 黄河下游水鸟面临主要威胁}

黄河三角洲湿地在全球水鸟保护中占有重要 地位, 作为东亚-澳大利西亚候鸟迁徙的重要通道, 其水鸟多样性和种群变化受到全球广泛关注(Wang et al, 2001; 李群等, 2006)。黄河干流水利工程的建 设形成清水下泄，对河槽产生冲刷，悬河减少，由 悬河引发的洪水灾害问题得到解决，但随之引发的 湿地水文节律变化等生态问题凸显，洪泛平原等湿 地面积减少，水鸟适宜栖息地面积减少。水量减少 导致黄河下游水资源短缺，引发断流，严重威胁水 鸟种群(李政海等, 2007; 沈彦俊等, 2018; 田冰, 2018)。

河口三角洲湿地资源丰富, 但面临河道断流、 入海水量减少、河口淡水三角洲湿地退化、外来种 入侵等问题(王延贵等，2018; 张金良等，2018)。 2000年之前，由于泥沙的淤积，黄河三角洲湿地以 平均每年2,000-3,000 ha的速度形成新的滨海陆地。 之后，受黄河来水水沙限制，淤积速率逐年减弱， 有些近海滩区已消失(郎坤等，2019; 李冬雪等， 
2020)。通过卫星遥感影像解译发现, 1984-2000年河 口湿地面积减少了 $50 \%$ 以上, 其生物多样性遭到严 重破坏, 水鸟适宜栖息地大面积减少, 水鸟种群数 量下降(董林水等, 2018; 张晓龙等, 2007)。

外来物种入侵是黄河三角洲湿地水鸟保护面 临的另一重要问题。自20世纪60年代以来, 黄河三 角洲区域的互花米草(Spartina alterniflora)面积逐 年递增, 有研究显示, 2010-2015年互花米草年均变 化率为91\%, 总面积约2,000 ha (刘明月, 2018)。互 花米草的入侵对滨海湿地生态系统产生了重要影 响, 对植物群落、底栖生物群落结构影响较大, 进 而影响滨海湿地水鸟食源和栖息地质量, 对水鸟多 样性产生重要影响。有数据显示, 米草(Spartina anglica)分布区的鸟种数量仅为非米草分布区乌种 数量的30\% (朱士文等, 2012)。

\section{黄河流域湿地水鸟多样性保护现状}

\section{1 黄河流域自然保护地体系建设现状}

截至2017年底，黄河流域共有湿地类型自然保 护地230处。其中, 包括三江源和祁连山国家公园2 处; 若尔盖、黄河三角洲、新乡黄河湿地水鸟、河 南黄河湿地等国家级自然保护区9处, 省级湿地类 型自然保护区54处，县级自然保护区14处，国家湿 地公园145处, 省级湿地公园6处。有青海扎陵湖湿 地、青海鄂陵湖湿地、四川若尔盖湿地国家级自然 保护区、鄂尔多斯遗鸥国家级自然保护区和山东黄 河三角洲湿地等国际重要湿地5处。共有湿地保护 面积255.67万ha，湿地保护率为65.1\%。与2013年全 国第二次湿地资源调查结果(国家林业局，2015)相 比，4年间黄河流域的湿地保护面积增加了 23.1万ha, 湿地保护率增加了 $5.8 \%$, 对黄河流域的湿地水鸟形 成了有效保护。

尽管黄河流域湿地保护地空间上能够满足湿 地水鸟的保护需求, 但存在保护地空间及管理上交 叉重叠和保护管理目标不明确等问题, 管理体制机 制有待进一步理顺，管理有效性有待提高。

\section{2 黄河流域水资源保护管理现状}

2001年由黄河流域水资源保护局编制完成了 《黄河流域水资源保护规划》，详细分析了黄河流 域的水资源开发利用、流域社会经济和自然环境状 况, 为解决黄河断流、水资源分配不均等问题, 实 现黄河流域水生态良性循环、水资源永续利用和促
进社会经济的可持续发展提供了重要保障。

为了有效解决黄河水资源合理利用问题，经国 务院第142次常务会议通过，2006年8月开始实施

《黄河水量调度条例》(以下简称“条例”, http://www. gov.cn/zwgk/2006-07/28/content_348927.htm/)。该条 例通过水量分配、水量调度、应急调度、监督管理 和法律法规等方面，规范了黄河流域水资源管理， 旨在加强黄河水量的统一调度，实现黄河水资源的 可持续利用，促进黄河流域及相关地区经济社会发 展和生态环境的改善。该条例的实施也为黄河流域 的湿地保护与管理提供了重要保障, 有效解决了黄 河流域断流、水鸟栖息地面积萎缩等问题。

\section{3 黄河流域主体功能区及生态补偿试点建设}

全国生态功能区划将黄河流域湿地生态系统 的主导功能划分为土壤保持、水源涵养、洪水调蓄、 生物多样性保护和防风固沙等(图1)。近年来, 为了 更好地发挥黄河流域湿地生态系统的服务功能, 针 对黄河流域不同区域，积极推动生态功能区管理体 系建设。

黄河上游主要是江河源区、内蒙古高原陇中荒 漠草原和高寒草甸生态区，主要实现生物多样性保 护、水源涵养和防风固沙等服务功能(王瑞玲等, 2013)。该区有三江源湿地和若尔盖湿地2处国际重 要湿地, 为禁止开发区和重点生态功能区; 玛曲湿 地和曼则塘湿地 2 处省级重要湿地为重点生态功能 区(国家林业局, 2015)。

黄河中游以农业、草原生态区为主，有黄土高 原农业与草原生态区、内蒙古中部草原生态区、汾 渭盆地农业生态区、燕山-太行山山地落叶阔叶林 生态区等。重要湿地主要为黄河漫滩、侧渗补给湿 地，主要提供水源涵养、土壤保持、防风固沙等服 务功能(郑志飞, $2007^{\circledR}$; 张金良等, 2018)。该区有河 南黄河湿地和新乡黄河湿地2处国家级重要湿地, 为禁止开发区; 黄河三门峡湿地、青铜峡库区湿地、 乌梁素海湿地、沙湖湿地、杭锦淖尔湿地、南海子 湿地、陕西黄河湿地、运城湿地、郑州黄河湿地和 开封柳园口湿地10处省级重要湿地, 其中黄河三门 峡湿地为重点开发区域，其余均为限制开发区(国 家林业局, 2015; 李山羊等, 2016)。黄河三门峡和青 铜峡库区湿地为黄河干流水库, 作为黄河流域的重

(1) 郑志飞 (2007) 黄河下游水量水质与生态联合调度系统研究. 硕士 学位论文, 河海大学, 南京. 


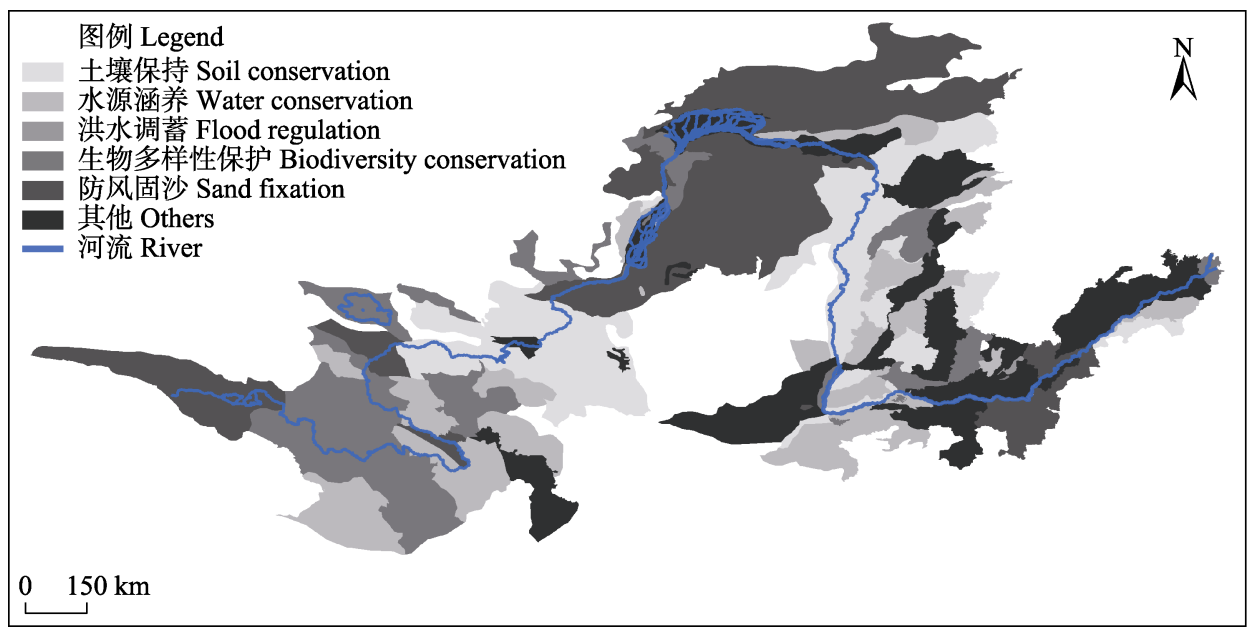

图1 黄河流域生态功能区

Fig. 1 The ecological function zones of the Yellow River basin

大水利枢纽(国家林业局, 2015), 对黄河干流具有重 要的水量调蓄等功能。而乌梁素海、沙湖、杭锦淖 尔、南海子湿地则为黄河漫滩侧渗补给湿地, 主要 发挥水土保持、防风固沙等功能(王瑞玲等, 2013)。

黄河下游以华北平原农业生态区为主, 重要湿 地为黄河三角洲湿地, 为国家级重要湿地, 是禁止 开发区。具有人工引黄河水补给湿地的功能, 主要 提供防风固沙、水源涵养和生物多样性保护等服务 功能(张晓龙等, 2009; 宋红丽等, 2019; 李冬雪等, 2020)。

2020年4月由财政部、生态环境部、水利部和 国家林业和草原局四部委联合发布了《支持引导黄 河全流域建立横向生态补偿机制试点实施方案》(以 下简称《方案》)。该《方案》深入贯彻习近平总书 记在黄河流域生态保护和高质量发展座谈会及中 央财经委员会第六次会议上的重要讲话精神, 提出 建立黄河流域生态补偿机制管理平台、中央财政安 排引导资金和鼓励地方加快建立多元化横向生态 补偿机制等措施，加快构建流域综合管理体制机制， 推动黄河流域共抓大保护, 协同推进大治理, 为水 鸟栖息地保护提供了有力保障。

\section{4 黄河流域湿地水鸟保护存在的问题及建议}

本文针对黄河流域湿地水鸟资源特色及其保 护面临的主要问题, 提出了黄河流域湿地保护体系 建设、湿地生态修复、流域综合管理及能力建设等 方面的建议, 为进一步保护黄河流域湿地水鸟提供 参考。

\section{1 完善黄河流域自然保护地体系建设}

黄河流域自然保护地体系建设需与国家保护 地体系建设衔接, 建设以国家公园为主体、自然保 护区为基础、湿地公园为补充的保护体系，填补保 护地空缺。应利用好世界自然遗产、东亚一澳大利 西亚迁飞网络、国际湿地城市、国际重要湿地等全 球化保护管理平台, 提升区域湿地保护管理能力。 根据国家公园生态系统完整性、原真性保护, 全民 公益、全民共享的基本原则, 结合黄河流域湿地空 间分布与候鸟栖息地关键节点的格局，建设黄河源 头的三江源国家公园和若尔盖国家公园，以及黄河 三角洲国家公园，在中游布局一批国家级自然保护 区，在城市周边布局数量众多的湿地公园。

\subsection{1 增设国家公园}

(1)三江源国家公园黄河源区。黄河上游的湿地 主要分布在黄河源区, 为禁止和限制开发区, 水功 能区保护和水源涵养是该区湿地保护的重点。该区 生态脆弱性较高, 应以源头湿地保护为重点, 上游 湿地保护为主体，建立黄河源区及上游水鸟栖息地 保护体系。该区现已建立三江源国家公园，为源头 区湿地资源及关键水鸟栖息地的保护提供了保障。 扎陵湖-鄂陵湖和星星海保护区整合为三江源国家 公园黄河源区，总面积191万ha。对三 江源国家公园 黄河源区的黑颈鹤、赤麻鸭、斑头雁等水鸟形成了 有效保护。

(2)祁连山国家公园。为维护青藏高原生态平 衡、维持绿洲稳定、保障黄河流域和河西内陆河径 流补给的重任, 甘肃、青海两省整合了甘肃祁连山 
国家级自然保护区、甘肃盐池湾国家级自然保护区 和青海祁连山省级自然保护区, 以及甘肃天祝三峡 国家森林公园、甘肃马蹄寺省级森林公园、甘肃冰 沟河省级森林公园和青海仙米国家森林公园、青海 祁连黑河源国家湿地公园, 共同建立了祁连山国家 公园，总面积502.37万ha。对黄河流域上游黑颈鹤、 蓑羽鹤、灰鹤、大白鹭、大天鹅、斑头雁、赤麻鸭 等湿地水鸟的关键栖息地形成了有效保护。

(3)若尔盖国家公园。根据河源区湿地空间分布 特征及湿地资源特色, 建议整合若尔盖县的 1 个国 家级、 2 个省级、 2 个县级自然保护区，以及红原、 阿坝和甘肃省玛曲县、碌曲县在内的各类保护地, 建设若尔盖国家公园(张国钢等, 2013; 马骅等, 2019)。

(4)黄河三角洲国家公园。理顺黄河三角洲湿地 保护管理体制机制，建立以黄河三角洲国家公园为 主体的河口湿地保护体系, 提高河口湿地保护管理 效率。对黄河三角洲等水鸟栖息地实行严格保护, 减少人类活动干扰, 在现有保护地的基础上, 实现 科学管理、提高保护有效性是该区水鸟保护需要解 决的关键问题。近年来, 国际社会对黄河三角洲湿 地保护工作的关注度不断提高, 国家和地方政府也 正在大力推动黄河三角洲作为黄渤海湿地世界自 然遗产二期申报的重点区域。如何利用好世界自然 遗产的国际化平台, 加强黄河三角洲湿地的保护管 理, 以及如何利用世界自然遗产的全球品牌效应, 提高其湿地生态系统的服务功能, 是未来黄河三角 洲湿地水鸟资源保护与合理利用需要考虑的关键 问题。

\subsection{2 晋升国家级自然保护区}

建议在现有黄河湿地国家级自然保护区、郑州 黄河国家级自然保护区和滨州贝壳堤岛与湿地国 家级自然保护区基础上, 晋升沙湖和乌梁素海为国 家级自然保护区。这些区域为鹤类、雁鸭类、彻埇岛 类等提供了重要的迁徙停歇地, 尤其是滨州贝壳堤 岛与湿地国家级自然保护区为行䂆鸟类提供了繁殖 地和停歇地; 乌梁素海为全球超过 $16 \%$ 的疮鼻天 我、 $35.6 \%$ 的白骨顶和 $7.8 \%$ 的红嘴鸥提供了繁殖栖 息地。鉴于上述区域已满足迁飞区鸟区网络纳入的 标准, 即满足其支持IUCN易危、濒危、极度濒危物 种或受威胁的生态群落; 或定期支持 20,000 只或更 多的迁徙水鸟; 或定期地支持超过一个迁徙水鸟种
群或亚种某一种群 $1 \%$ 的个体，建议将上述国家级 及需晋升国家级的自然保护区纳入迁飞区鸟区网 络。通过全球迁飞水鸟的协同保护，以国际化的建 设及管理标准进行管理，提高水鸟保护有效性与管 理效率。

\subsection{3 建设湿地公园}

结合黄河流域湿地水鸟的分布情况、湿地资源 的空间分布特点、社会经济发展状况以及流域国家 公园、自然保护区等保护地布局，依据湿地公园建 设的标准和要求，建设以黄河流域湿地资源保护为 主，兼顾区域社会经济发展需求的湿地公园，对国 家公园和自然保护区保护空缺进行补充，对黄河流 域湿地水鸟形成完整有效的保护。

\section{2 推进黄河流域湿地水鸟栖息地修复}

黄河流域的东西跨度大，水鸟多样性资源空间 分布差异性较大，从黄河源头到河口湿地水鸟多样 性保护面临的问题不同，其湿地水鸟栖息地修复所 要解决的问题也存在差异。

上游湿地为中亚水鸟迁徙的重要通道及斑头 雁、黑颈鹤等珍稀濒危水鸟的重要栖息地，为有效 解决水鸟数量下降的趋势，需对该区关键水鸟制定 科学有效的保护行动计划(郭斌等, 2018; 赵娜娜等, 2019)。黄河源区受全球气候变化的影响, 生态系统 类型发生变化, 关键湿地水鸟栖息地变化或丧失。 通过对关键水鸟栖息地进行近自然恢复，减少人类 活动的干扰，降低其变化和丧失的速度，扩大栖息 地面积, 应对全球气候变化, 减缓气候变化对湿地 水鸟的影响, 是该区湿地水鸟栖息地修复需要解决 的关键问题(高红梅等, 2019)。

黄河中游地区湿地是大鸨、黑鹳、大天鹅、青 头潜鸭等珍稀濒危水鸟的重要栖息地。处理好黄河 两岸湿地与工农业发展之间的关系是中游水鸟栖 息地保护修复的关键。时良等(2009)对黄河中游湿 地1998-2008年越冬水鸟的调查发现, 其水鸟种群 数量均呈现下降的趋势, 其中大铇、疮鼻天鹅、青 头潜鸭等的种群数量均下降 $50 \%$ 以上。减少黄河中 游湿地的点面源污染对水鸟栖息地及水鸟食源的 影响是中游湿地水鸟种群保护的主要目标。做好黄 河中游湿地的保护恢复, 需重点抓好流域水土保持 和污染治理，部分区域要以自然恢复为主，减少人 为干扰，对水体污染严重的支流，需着力推进湿地 生态环境治理工程, 恢复湿地生态功能。在自然条 
件允许的地方, 要大力建设旱作梯田、淤地坝等, 为大铇等关键物种保护提供适宜生境和优质食源。

黄河三角洲是黄河下游湿地水鸟保护的重点 区域。作为黄渤海湿地的重要组成部分, 黄河三角 洲的生物多样性资源丰富, 是东亚-澳大利西亚水 鸟迁飞路线的重要繁殖、越冬和停歇地。近年来, 黄 河三角洲湿地水鸟多样性发生了较大变化, 2008-2014年间，其水鸟种数由 2008年的 72种减少 到了 2014年的45种，减少了 $20 \%$ 以上(王刚，2010 ${ }^{\circledR}$; 黄子强等, 2018b)。如何着力做好下游河段地上悬河 治理和风险防控工作, 促进河流生态系统健康, 加 强滨海湿地水鸟栖息地的保护管理，提高水鸟多样 性，是黄河下游湿地作为水鸟栖息地保护与修复的 重点。同时, 互花米草、泥螺等入侵物种防控治理 工程的实施也是黄河三角洲水鸟栖息地修复需要 解决的关键问题。

\section{3 实施流域综合管理}

构建黄河流域生态补偿机制, 广开资金来源, 为黄河流域关键候鸟栖息地的保护与修复提供资 金保障，建立全流域的湿地监测与第三方评估机制， 支持并提高黄河流域湿地保护网络的运行效率, 推 动黄河流域综合管理各项制度和机制的落实。黄河 水利委员会机构现有职责主要以水资源管理为主, 包括流域水资源的合理开发利用、管理和监督及保 护; 流域内的水旱灾害防治、水文监测管理、水资 源开发、水土流失防治、水政监察和水行政执法、 农村水利及水能资源开发、流域控制性水利工程管 理等(胡国华等, 2004; 傅小城等, 2010)。在现有生 态文明建设大背景下, 需要将其职能进一步扩展到 全流域, 包括水鸟资源等各生态要素的管理、加强 黄河流域保护管理能力建设, 尤其是水鸟监测、研 究、保护和栖息地管理人才的培养; 建立全流域科 研监测体系，提高黄河流域湿地水鸟资源的保护有 效性和管理效率。

在黄河上游, 建议以三江源、祁连山、甘南黄 河上游、川西北高原湿地水源涵养区等为重点, 推 进实施一批重大生态保护修复和建设工程, 提升该 区湿地生态系统的水源涵养能力, 做好黄河上游城 市化和农业灌溉引发的点面源污染防控工作，是上 游流域综合治理的关键(陈孝泉和苟新京, 2002; 王

(1) 王刚 (2010) 黄河三角洲湿地鸟类群落研究. 硕士学位论文, 曲阜师 范大学, 曲阜.
树洲和魏智, 2005)。

黄河中游流域综合管理的关键是解决工农业 生产导致的点面源污染问题。银川平原、河套平原 黄灌区农业灌溉回水引发黄河流域湿地面源污染, 农田的引黄灌溉水中盐分含量较高导致土壤盐渍 化。有研究显示, 2000年前后河套平原每年引黄水 量50亿吨以上，累积灌区总盐量约有 185 万吨，其 中有害盐分占比近 $30 \%$ 。内蒙古区域内的黄河水系 主要受呼和浩特和包头工业废水、生活污水和垃圾 等严重污染，其排放量占内蒙古自治区排放总量约 49\% (郝向英等, 2000; 黄锦辉等, 2006)。

除解决上、中、下游及河口区域各自存在的关 键问题外，作为流域生态系统，黄河流域湿地的水 鸟多样性保护还需要协调上、中、下游之间的关系, 利用流域综合管理的手段与方法解决区域间湿地 资源的合理配置、污染治理、合理利用等问题，保 护黄河流域湿地水鸟多样性和湿地生态系统完整 性，真正实现黄河流域湿地生态可持续发展。

\section{参考文献}

Almond REA, Grooten M, Petersen T (2020) WWF (2020) Living Planet Report 2020-Bending the Curve of Biodiversity Loss. WWF, Gland.

Alonso JC, Palacin C (2010) The world status and population trends of the great bustard (Otis tarda): 2010 Update. Chinese Birds, 1(2), 141-147.

Cao JY, Wang N, Qiao ZX, Ding YY, Liu Y (2018) Coupling analysis of urbanization and economic transformation in the Yellow River basin. Henan Science, 36, 1288-1296. (in Chinese with English abstract) [曹静宇, 王妞, 乔增轩, 丁 银盈, 刘勇 (2018) 黄河流域中心城市城镇化与经济转 型耦合分析. 河南科学, 36, 1288-1296.]

Chen Y (2019) The strategy of the thinking point of the ecological conservation and the high quality development of the Yellow River basin. Regional Economic Review, (1), 8-11. (in Chinese) [陈耀 (2019) 黄河流域生态保护和高 质量发展战略的思考要点. 区域经济评论, (1), 8-11.]

Chen XQ, Gou XJ (2002) Research on the Eco-environmental Protection in the Source Regions of the Yangtze, Yellow and Lancang rivers. Qinghai People's Press, Xining. (in Chinese) [陈孝泉, 苟新京 (2002) 三江源自然保护区生 态环境. 青海人民出版社, 西宁.]

Cristina GM, Russell AM, Tracy AF, Lan JH, Amy JU, Thomas MB (2010) Fresh Water the Essence of Life. PEFC Certified Paper, Beijing.

Dong LS, Song AY, Ren YH, Mei ZX, Liu X (2018) Avian diversity of different habitats in typical city of the Yellow River delta. Journal of Arid Land Resources and Environment, 32, 156-162. (in Chinese with English 
abstract) [董林水, 宋爱云, 任月恒, 梅增霞, 刘霄 (2018) 黄河三角洲地区城市绿地鸟类多样性研究. 干旱区资源 与环境, 32, 156-162.]

Dou L, Li H, Li FS, Zhang M, Zheng ZR, Ran JH (2013) Survey on the black-necked cranes during the breeding period at Sichuan Ruoerggai Wetland National Nature Reserve. Sichuan Journal of Zoology, 32, 77T03. (in Chinese with English abstract) [窦亮, 李华, 李凤山, 张曼, 郑志荣, 手江洪 (2013) 四川若尔盖湿地国家级自然保 护区繁殖期黑颈鹤调查. 四川动物, 32, 770-773.]

Du JZ, Wang GX, Yang Y, Zhang T, Mao TX (2015) Temporal and spatial variation of the distributive pattern and driving force analysis in the Yangtze River and Yellow River source regions wetland. Acta Ecologica Sinica, 35, 61736182. (in Chinese with English abstract) [杜际增, 王根绪, 杨燕, 张 涛, 毛天旭 (2015) 长江黄河源区湿地分布的时空变化 及成因. 生态学报, 35, 6173-6182.]

Fan J, Wang YF, Wang YX (2020) High quality regional development research based on geographical units: Discuss on the difference in development conditions and priorities of the Yellow River basin compared to the Yangtze River basin. Economic Geography, 40(1), 111. (in Chi nese with English abstract) [樊杰, 王亚飞, 王怡轩 (2020) 基于地 理单元的区域高质量发展研究一一兼论黄河流域同长江 流域发展的条件差异及重点. 经济地理, 40(1), 1-11.]

Fu XC, Ye L, Xu YY, Cai QH (2010) Survey of water quality and benthos in the Yellow River basin. Ecological Science, 29, 1-7. (in Chinese with English abstract) [傅小城, 叶麟, 徐耀阳, 蔡庆华 (2010) 黄河主要水系水环境与底栖动 物调查研究. 生态科学, 29, 1-7.]

Gao HM, Cai ZY, Qin W, Huang YG, Wu T, Chi XW, Zhang JJ, Miao ZY, Song PF, Lian XM, Zhang TZ (2019) Species diversity of birds in the Three-River-Source National Park. Acta Ecologica Sinica, 39, 8254-8270. (in Chinese with English abstract) [高红梅, 蔡振媛, 覃雯, 黄岩洤, 吴粀, 迟翔文, 张婧捷, 苗紫燕, 宋鹏飞, 连新明, 张同作 (2019) 三江源国家公园鸟类物种多样性研究. 生态学报, 39, 8254-8270.]

Gao P (2010) Streamflow and Sediment Discharge Change Trend and Its Response to Human Activities in the Middle Reaches of the Yellow River. PhD dissertation, University of Chinese Academy of Sciences, Beijing. (in Chinese with English abstract) [高鹏 (2010) 黄河中游水沙变化及其对 人类活动的响应. 博士学位论文, 中国科学院研究生院, 北京.]

Gao ZJ, Feng GP (2020) Analysis on the trend and cause of water and sediment in the Yellow River. Ground Water, 42(1), 147-151. (in Chinese with English abstract) [高宗军, 冯国平 (2020) 黄河水沙变化趋势及成因分析. 地下水, 42(1), 147-151.]

Grabas GP, Crewe TL, Timmermans S (2008) Bird Community Indicators. Ramsar Convention Secretariat, Gland.

Guo B, Wang S, Zhang H, Wang MT (2018) Change characteristics of growth period of natural grass in Zoige wetland and its response to climate change. Plateau and
Mountain Meteorology Research, 38(2), 49-57. (in Chinese with English abstract) [郭斌, 王珊, 张菡, 王明田 (2018) 若尔盖湿地天然牧草生育期变化特征及其对气候变化的 响应. 高原山地气象研究, 38(2), 49-57.]

Hao XY, Hong X, Wu D, Guo BS (2000) Present situation of water environment in the middle reach of the Yellow River. Journal of inner mogolia technology and economy, 6(1), 42-65. (in Chinese) [郝向英, 红霞, 乌地, 郭博书 (2000) 黄河中游水体水环境现状. 内蒙古科技与经济, 6(1), 42-65.]

He B, Wang BX (2018) The value of wetland ecosystem services in Shaanxi Yellow River Wetland Provincial Nature Reserve. Shaanxi Forest Science and Technology, 46(6), 104-109. (in Chinese with English abstract) [何冰, 王保星 (2018) 陕西黄河湿地省级自然保护区湿地生态系统服务 价值研究. 陕西林业科技, 46(6), 104-109.]

Hu GH, Zhao PL, Xiao XQ (2004) Sediment characteristics of Yellow River and their influence on water environment. Water Resources and Hydropower Engineering, 35(8), 17-20. (in Chinese with English abstract) [胡国华, 赵沛伦, 肖翔群 (2004) 黄河泥沙特性及对水环境的影响. 水利 水电技术, 35(8), 17-20.]

Huang JH, Shi XX, Zhang Q, Li CY, Xu XL (2006) Characteristic of ecological system and target identification of ecological protection of the Yellow River. Soil and Water Conservation in China, (12), 14-17, 56. (in Chinese with English abstract) [黄锦辉, 史晓新, 张蓄, 李翠玉, 徐晓琳 (2006) 黄河生态系统特征及生态保护目标识别. 中国水 土保持, (12), 14-17, 56.]

Huang ZQ, Che CG, Tan HT, Bi ZG, Liu WH, Zhang XT, Zhang SY, Li DL (2018a) Investigation on the diversity and population of waterbird in the Yellow River Delta Nature Reserve. Shandong Forestry Science And Technology, (2), 41-45, 48. (in Chinese with English abstract) [黄子强, 车 纯广, 谭海涛, 毕正刚, 刘伟华, 张希涛, 张树岩, 李东 来 (2018a) 黄河三角洲水鸟多样性调查及种群数量监测. 山东林业科技, (2), 41-45, 48.]

Huang ZQ, Guan S, Jin LY, Zhang SY, Che CG, Zhu SY, Li DL (2018b) Composition and diversity of waterbirds' community in north of the Yellow River Estuary in 2016. Wetland Science, 16, 735-741. (in Chinese with English abstract) [黄子强, 关爽, 金麟雨, 张树岩, 车纯广, 朱书 玉, 李东来 (2018b) 2016年黄河入海口北侧水鸟群落组 成及多样性. 湿地科学, 16, 735-741.]

Investigation Planning and Design Institute of State Forestry Administration (2016) The Digital Map of Chinese Wetland Resources: Yellow River Basin. China Forestry Publishing House, Beijing. (in Chinese) [国家林业局调查规划设计院 (2016) 中国湿地资源电子图集：黄河流域. 中国林业出 版社, 北京.]

Lang K, Zhao GX, Wang WQ, Zhang SM, Xiao Y (2019) Analysis of the land use dynamic characteristics in the typical region of the Yellow River delta for the last 10 years. Geospatial Information, 17(5), 75-80. (in Chinese with English abstract) [郎坤, 赵庚星, 王文倩, 张素铭, 肖杨 
(2019) 黄河三角洲典型区近10a土地利用动态特征分析. 地理空间信息, 17(5), 75-80.]

Li CK, Li J, Deng PY, Ma C, Li ZX (2019) Analysis of the avifauna and species diversity of birds in the natural wetland park along Minquan ancient Yellow River course. Journal of Henan Agricultural University, 53, 591-600. (in Chinese with English abstract) [李长看, 李杰, 邓培渊, 马超, 李忠 信 (2019) 民权黄河故道国家湿地公园鸟类区系和物种 多样性分析. 河南农业大学学报, 53, 591-600.]

Li CK, Zhang GY, Wang W (2010) Research on the impact of global warming on the birds distribution of Zhengzhou Yellow River wetland. Journal of Anhhui Agricultural Sciences, 38, 2962-2963, 2990. (in Chinese with English abstract) [李长看, 张光宇, 王威 (2010) 气候变暖对郑州 黄河湿地鸟类分布的影响. 安徽农业科学, 38, 2962-2963, 2990.]

Li CK, Zhao HP, Deng PY, Zhao ZY, Li ZZ (2013) The avifauna and diversity of birds in Zhengzhou Yellow River Wetland Provincial Nature Reserve. Journal of Henan University (Natural Science), 43, 416-422. (in Chinese with English abstract) [李长看, 赵海鹏, 邓培渊, 赵宗英, 李振 中 (2013) 郑州黄河湿地省级自然保护区鸟类区系和多 样性. 河南大学学报(自然科学版), 43, 416-422.]

Li DX, Xie T, Ma X, Cui BS, Wu X, Che CG, Zhang XT (2020) Temporal and spatial pattern evolution of hydrological connectivity of the old track of Yellow River in Diaokouhe from 1985 to 2015. Environmental Ecology, 2, 10-16. (in Chinese with English abstract) [李冬雪, 谢湉, 马旭, 崔保山, 吴霞, 车纯广, 张希涛 (2020) 1985-2015 年ᄀ口河黄河故道区域河流水文连通时空演变规律. 环 境生态学, 2, 10-16.]

Li FX, Chang GG, Xiao JS, Zhou BR, Fu Y (2009) Relationship between wetlands changes and climate change in the Yellow River source region. Journal of Natural Resources, 24, 683-690. (in Chinese with English abstract) [李凤霞, 常国刚, 肖建设, 周秉荣, 伏洋 (2009) 黄河源 区湿地变化与气候变化的关系研究. 自然资源学报, 24 , 683-690.]

Li JH, Feng L, Wu LQ (2004) Genetic analysis of water interception of Yellow River. Northwest Hydropower, (3), 58-61. (in Chinese with English abstract) [李建华, 冯黎, 吴来群 (2004) 黄河断流的成因分析. 西北水电, (3), 58-61.]

Li Q, Yan SX, Yan L, Huang JH, Zhao Y (2006) The human activity influence on the Yellow River wetland and birds' ecological habitat-For example with the white swan garden of the Yellow River of Sanmenxia. Henan Science, 24, 749-753. (in Chinese with English abstract) [李群, 问双喜, 阎亮, 黄锦辉, 赵勇 (2006) 人类活动对黄河湿地鸟类生 态栖息地影响——三门峡黄河白天鹅观赏园建设为例. 河南科学, 24, 749-753.]

Li SH, Meng WY, Chen LX, Li YF, Gao RY, Ru WD, Sun MH, Dai Q, Zhang GG, Lu J (2017) The spring waterbird community and home range of the whooper swan (Cygnus cygnus) at the upper and middle reaches of Yellow River in Inner Mongolia, China. Chinese Journal of Ecology, 36, 1910-1916. (in Chinese with English abstract) [李淑红, 孟 维悦, 陈丽霞, 李云锋, 高如意, 茹文东, 孙孟和, 戴强, 张国钢, 陆军 (2017) 黄河中上游春季迁徙期水鸟群落 及大天鹅活动特征. 生态学杂志, 36, 1910-1916.]

Li SY, Guo HM, Huang SF, Ma JW, Liu HY, Sun YY (2016) Variation in Hetao basin wetlands from 1973 to 2014. Resources Science, 38(1), 1929. (in Chinese with English abstract) [李山羊, 郭华明, 黄诗峰, 马建威, 刘海燕, 孙 亚勇 (2016) 1973-2014年河套平原湿地变化研究. 资源 科学, 38(1), 19-29.]

Li ZH, Wang HM, Han GD, Han JW, Gao JX (2007) Review on the flow-break in the lower reaches of Yellow River. Ecology and Environment, 16, 686690. (in Chinese with English abstract) [李政海, 王海梅, 韩国栋, 韩经纬, 高吉 喜 (2007) 黄河下游断流研究进展. 生态环境, 16, 686690.]

Li ZXJ, Zeng Q, He YB, Duo HR, Wen L, Lei GC (2017) Response model of egg-laying and incubation dates of Anser indicus at Dan Island in Qinghai Lake to air temperature and normalized differential vegetation index. Wetland Science, 15, 369-374. (in Chinese with English abstract) [李扎西姐, 曾晴, 何玉邦, 朵海瑞, 文力, 雷光春 (2017) 青海湖蛋 岛斑头雁产卵及孵化日期对气温和归一化植被指数的响 应模型. 湿地科学, 15, 369-374.]

Liu JQ, Zhang BH, Li YZ, Yu LJ, Wu XQ (2017) Identification and zoning of wetland ecological red line in Yellow River delta. Environmental Science and Management, 42(12), 146-150, 173. (in Chinese with English abstract) [刘佳琦, 张保华, 栗云召, 于良巨，吴晓青 (2017) 黄河三角洲湿 地生态保护红线区选划研究. 环境科学与管理, 42(12), 146-150, 173.]

Liu MY (2018) Romote Sensing Analysis of Spartina alterniflora in the Coastal Areas of China During 1990 to 2015. PhD dissertation, Northeast Institute of Geography and Agroecology, Chinese Academy of Sciences, Changchun. (in Chinese with English abstract) [刘明月 (2018) 中国滨海湿地互花米草入侵遥感监测及变化分 析. 博士学位论文, 中国科学院东北地理与农业生态研 究所, 长春.]

Lu YJ, Wang D, Deng SX (2018) Environmental assessment and ecological impact of wetland in the Yellow River Delta. Sichuan Environment, 37(3), 141-146. (in Chinese with English abstract) [芦英俊, 王东, 邓术兴 (2018) 黄河三 角洲湿地环境评价及生态影响. 四川环境, 37(3), 141-146.]

Ma H, Wang YF, Ning Y, Wu GJ, Guo JL, Tan YC, Li CY, Lin HY (2019) Dynamic analysis of landscape pattern of the plateau wetland of Zoige County. Forest Resources Management, (1), 109-115. (in Chinese with English abstract) [马骅, 王义飞, 宁宇, 武高洁, 郭菊兰, 谭月臣, 
李春义, 林海晏 (2019) 若尔盖县高原湿地景观格局动 态分析研究. 林业资源管理, (1), 109-115.]

Ma Q, Su HL, Li DQ (2003) Investigation of avifauna distribution in the water origin of Three Rivers Nature Reserve. Journal of Beijing Forestry University, 25(5), 51-54. (in Chinese with English abstract) [马强, 苏化龙, 李迪强 (2003) 青海三江源自然保护区鸟类分布状况初 步研究. 北京林业大学学报, 25(5), 51-54.]

Qi HT, Wang Y (2004) Water environmental protection issues in the development of water resources in natural river resources. Ground Water, 26(2), 142-144. (in Chinese with English abstract) [齐贺停, 汪雁 (2004) 天然河流水资源 开发中的水环境保护问题. 地下水, 26(2), 142-144.]

Ramsar Convention Secretariat (2018) Global Wetland Outlook: State of the World's Wetlands and Their Services to People. Ramsar Convention Secretariat, Gland.

Shen YJ (2018) Eco-environmental protection and sustainable utilization of water resources in the Yellow River basin. Democracy and Science, (6), 16-19. (in Chinese) [沈彦俊 (2018) 黄河流域生态环境保护与水资源可持续利用. 民 主与科学, (6), 16-19]

Shi L, Dong R, Yu XP (2009) Winter avian community of Yellow River wetland in Shaanxi. Chinese Journal of Zoology, 44, 83-93. (in Chinese with English abstract) [时 良, 董荣, 于晓平 (2009) 陕西省黄河湿地冬季鸟类群落 初步研究. 动物学杂志, 44, 83-93.]

Song HL, Mou XJ, Liu XT (2019) Anthropogenic effect on wetland vegetation growth in the Yellow River delta. Ecology and Environmental Sciences, 28, 2307-2314. (in Chinese with English abstract) [宋红丽, 牟晓杰, 刘兴土 (2019) 人为干扰活动对黄河三角洲滨海湿地典型植被生 长的影响. 生态环境学报, 28, 2307-2314.]

State Forestry Administration (2015) China Wetlands Resources. China Forestry Publishing House, Beijing. (in Chinese) [国家林业局 (2015) 中国湿地资源. 中国林业 出版社, 北京.]

Tian B (2018) The review of the studies in recent decades on ecological environment evolution and vicissitude of the towns and cities in the middle and lower reaches of the Yellow River. Journal of Pingdingshan University, 33(6), 72-79. (in Chinese with English abstract) [田冰 (2018) 近 几十年来黄河中下游地区生态环境变迁与城镇兴衰研究 综述. 平顶山学院学报, 33(6), 72-79.]

Wang GX, Ding YJ, Wang J, Liu SY (2004) Land ecological changes and evolutional patterns in the source regions of the Yangtze and Yellow rivers in recent 15 years. Acta Geographica Sinica, 59, 163-173. (in Chinese with English abstract) [王根绪, 丁永建, 王建, 刘时银 (2004) 近15年 来长江黄河源区的土地覆被变化. 地理学报, 59, 163173.]

Wang GX, Qian J, Cheng GD (2001) Eco-environmental degradation and causal analysis in the source region of the Yellow River. Environmental Geology, 40, 884-890.
Wang RL, Lian Y, Wang XG, Hao FQ, Peng B, Huang JH, Lou GY, Ge L (2013) Study on the overall framework of water ecological protection and restoration of the Yellow River basin. Yellow River, 35(10), 107-114. (in Chinese with English abstract) [王瑞玲, 连煜, 王新功, 郝伏勤, 彭勃, 黄锦辉, 娄广艳, 葛雷 (2013) 黄河流域水生态保护与修 复总体框架研究. 人民黄河, 35(10), 107-114.]

Wang YG, Chen K, Chen Y, Liu Q (2018) Variations in runoff and erosion and their distributions in the Yellow River basin. Science of Soil and Water Conservation, 16(5), 120-128. (in Chinese with English abstract) [王延贵, 陈康, 陈吟, 刘茜 (2018) 黄河流域产流侵蚀及其分布特性的 变异. 中国水土保持科学, 16(5), 120-128.]

Wang SZ, Wei Z (2005) Countermeasures for urban water environment construction in the upper reaches of the Yellow River basin. Rural Water Conservancy and Hydropower in China, (11), 46-48. (in Chinese) [王树洲, 魏智 (2005) 黄 河流域上游城市水环境建设对策. 中国农村水利水电, (11), 46-48.]

Wen XJ, Yao SB (2018) Spatial and temporal changes of vegetation coverage reponse to human activity intensity in the middle and upper reaches of the Yellow River. Journal of Fujian Agriculture and Forestry University (Natural Science Edition), 47, 607-614. (in Chinese with English abstract) [温小洁, 姚顺波 (2018) 黄河中上游植被覆盖 与人类活动强度的时空动态演化. 福建农林大学学报 (自然科学版), 47, 607-614.]

Yan YP, Xu H, Xing Y, Liu G, Liu JY, Wang YF (2015) Response regularity of wetland area changing according to climate changes in the 3-river source area from 1975 to 2007. Bulletin of Surveying and Mapping, (S2), 5-10. (in Chinese) [燕云鹏, 徐辉, 邢宇, 刘刚, 刘建宇, 王怿飞 (2015) 1975-2007年间三江源不同源区湿地变化特点及 对气候变化的响应. 测绘通报, (S2), 5-10.]

Yang RR, Yi GH, Zhang TB, Li JJ, Bie XJ, Xia J, Shen YL (2018) Vegetation coverage change and how it drives climatic factors in the Zoige region from 2000 to 2015. Pratacultural Science, 35, 2822-2835. (in Chinese with English abstract) [杨瑞瑞, 易桂花, 张廷斌, 李景吉, 别小 娟, 夏杰, 申一林 (2018) 2000-2015年若尔盖地区植被 覆盖度变化及气候因子驱动分析. 草业科学, 35, 28222835.]

You YC, Li ZW, Li XL (2018) Land cover change in Zoige Plateau during 1990-2011. Advances in Science and Technology of Water Resources, 38 (2), 60-69. (in Chinese with English abstract) [游宇驰, 李志威, 李希来 (2018) 1990-2011年若尔盖高原土地覆盖变化. 水利水电科技进 展, 38 (2), 60-69.]

Zhang GG, Dai Q, Liu DP, Hou YQ, Lu J, Shen Y, Du K (2013) The seasonal dynamic on waterbird population at Ruoergai marshes, China. Chinese Journal of Zoology, 48, 742-749. (in Chinese with English abstract) [张国钢, 戴强, 刘冬平, 侯韵秋, 陆军, 沈尤, 杜科 (2013) 若尔盖湿地 
水鸟资源季节变化. 动物学杂志, 48, 742-749.]

Zhang HJ, Meng QW (2006) Evaluation on quality of shallow groundwater in lower reaches of Yellow River (Henan section). Ground Water, 28, 29-32. (in Chinese with English abstract) [张和军, 孟庆伟 (2006) 黄河下游(河南段)浅层 地下水质量评价. 地下水, 28, 29-32.]

Zhang JL, Liu SY, Bao RC, Zhang RH (2018) Ecological management mode of the lower Yellow River floodplain and impact assessment - "Study on ecological reconstruction and management of the floodplains in the lower Yellow River” (V). Y ellow River, 40(11), 1-4, 33. (in Chinese with English abstract) [张金良, 刘生云, 暴入超, 张瑞海 (2018) 黄河下游滩区生态治理模式与效果评价——“黄 河下游滩区生态再造与治理研究”之五. 人民黄河, 40(11), 1-4, 33.]

Zhang KX, Dong XG, Liao KT, Jiang ZC, Cao LG (2020) Characteristics of seasonal changes in extreme temperature and their relativity with ENSO in the Yellow River basin from 1960 to 2017. Research of Soil and Water Conservation, 27, 185-192. (in Chinese with English abstract) [张克新, 董小刚, 廖空太, 蒋志成, 曹立国 (2020) 1960-2017年黄河流域极端气温的季节变化特征 及其ENSO的相关性分析. 水土保持研究, 27, 185-192.]

Zhang SW (2005) Yellow River Annual Runoff Analysis and Its Forecast. PhD dissertation Sichuan University, Chengdu. (in Chinese with English abstract) [张少文 (2005) 黄河流 域天然年径流变化特征分析及其预测. 博士学位论文, 四川大学, 成都.]

Zhang W, Fu XF (2011) Present status of water ecology and countermeasures for adaptability of climate change of the Yelllow River basin. Yellow River, 33(5), 51-53, 150. (in Chinese with English abstract) [张威, 付新峰 (2011) 黄河 流域水生态现状与气候变化适应性对策. 人民黄河, 33(5), 51-53, 150.]

Zhang XL, Li P, Liu LJ, Li PY, Shan K (2009) Biodiversity and its protection in the Yellow River delta wetland. Coastal Engineering, 28(3), 33-39. (in Chinese with English abstract) [张晓龙, 李萍, 刘乐军, 李培英, 单凯 (2009) 黄河三角洲湿地生物多样性及其保护. 海岸工程, 28(3), 33-39.]

Zhang XL, Li PY, Liu YL, Xu XY, Cao CX, Shan K (2007) Studies on the wetland of the Yellow River delta A review. Marine Science, 31(7), 81-85. (in Chinese with English abstract) [张晓龙, 李培英, 刘月良, 徐兴永, 曹成效, 单 凯 (2007) 黄河三角洲湿地研究进展. 海洋科学, 31(7), 81-85.]

Zhang YM, Jiao SW, Jia YF, Zeng Q, Feng DD, Lei GC (2017) Spatial and temporal variations in waterbird communities and its implications for ecosystem management in a large temperate arid wetland of Northwest P. R. China. Avian Biology Research, 10, 119-128.
Zhao G, Gao M, Ling Y (2018) Analysis on dynamic change and its causes of Passeriformes in Wuliangsuhai during the last 30 years. Journal of Inner Mongolia Normal University (Natural Science Edition), 47, 507-510. (in Chinese with English abstract) [赵格日乐图, 高敏, 灵燕 (2018) 近30 年乌梁素海雀形目鸟类动态变化及原因分析. 内蒙古师 范大学学报(自然科学汉文版), 47, 507-510.]

Zhao NN, Wang HN, Zhang BB, Liu J, Xu WG, Yu YL (2019) Runoff variation in Zoige wetland basin and its response to climate change. Water Resources Protection, 35(5), 40-47. (in Chinese with English abstract) [赵娜娜, 王贺年, 张贝 贝, 刘佳, 徐卫刚, 于一雷 (2019) 若尔盖湿地流域径流 变化及其对气候变化的响应. 水资源保护, 35(5), 40-47.]

Zhao WZ, Wang HR, Zhao ZY, Liu BX, Guo L, Zhang JH, Li JP, Ma XF, Hao ZX (2018) Survey of the resources of great bustard wintering in Henan Province. Chinese Journal of Wildlife, 39, 685-688. (in Chinese with English abstract) [赵文珍, 王恒瑞, 赵宗英, 刘冰许, 郭凌, 张建华, 李进 萍, 马小峰, 郝志香 (2018) 河南省越冬大铇资源调查. 野生动物学报, 39, 685-688.]

Zhao Y, He F, He GH, Li HH, Wang LZ, Chang HY, Zhu YN (2020) Review the phenomenon of Yellow River cutoff from a whole perspective and identification of current water shortage. Yellow River, 42(4), 42-46. (in Chinese with English abstract) [赵勇, 何凡, 何国华, 李海红, 王丽珍, 常英宇, 朱永楠 (2020) 全域视角下黄河断流再审视与 现状缺水识别. 人民黄河, 42(4), 42-46.]

Zhao Y, Hu CH, Zhang XM, Wang YS, Cheng C, Yin XL, Xie $M$ (2018) Analysis on runoff and sediment regimes and its causes of the Yellow River in recent 70 years. Transactions of the Chinese Society of Agricultural Engineering, 34, 112-119. (in Chinese with English abstract) [赵阳, 胡春宏, 张晓明, 王友胜, 成晨, 殷小琳, 谢敏 (2018) 近70年黄 河流域水沙情势及其成因分析. 农业工程学报，34, 112-119.]

Zhu LF, Liu YY, Guo YM, Ban YT, Song KM, Niu HX, Bu YZ (2018) Wintering ecology of great bustard (Otis tarda) in Xinxiang Yellow River Wetland. Chinese Journal of Wildlife, 39, 584-587. (in Chinese with English abstract) [朱龙飞, 刘荣䒯, 郭玉明, 班永田, 宋克明, 牛红星, 卜 艳珍 (2018) 新乡黄河湿地大铇的越冬生态研究. 野生 动物学报, 39, 584-587.]

Zhu SW, Pan XL, Li XQ, Liu C (2012) Effects of exotic species Spartina anglica on ecological environment of the Yellow River delta. Shandong Agricultural Sciences, 44(3), 73-75, 83. (in Chinese with English abstract) [朱士文, 潘 秀莲, 李秀启, 刘超 (2012) 外来物种米草对黄河三角洲 生态环境的影响. 山东农业科学, 44(3), 73-75, 83.]

(责任编委: 李俊生 责任编辑: 黄祥忠) 